\title{
Research on Teaching Methods for Communication Engineering Students in Colleges
}

\author{
Jian Xiang \\ School of Information and Electronic Engineering, Zhejiang University of Science and Technology, Hangzhou, \\ China \\ Email: freenyspi@gmail.com
}

Received December 2013

\begin{abstract}
The purpose of communication engineering education in independent colleges is to develop application-oriented talents. In personnel training, we should consider the demand for training demand about the regional economy. It is necessary to make the majors improve and develop itself with regional economic developments. In this paper, we propose a series of effective strategies to solve our problems in personnel training in communications engineering education.
\end{abstract}

\section{Keywords}

Component, Teaching Methods, Research, Independent College, Students

\section{Introduction}

It is training the qualified engineering professionals in accordance with the national requirements is the teaching goal of the specialty of communication engineering. At present, the electronic and information technology shows a variety of trends of development [1].

On the one hand, due to the rapid development of the communication industry, the electronic devices such as optoelectronics, microelectronics, nanotechnology and microwave devices [2] and other new devices are emerging, which led to the emergence of the new systems.

On the other hand, in the fields of communications and electronic systems, including communications, broadcasting, radar navigation, satellite, remote sensing, aerospace, wireless and wired access networks, the development and application of new technologies [3] have got broader space as a result of the continuous emergence and improvement of new devices.

Besides, in terms of the demands of the country and society, to provide faster, better, and more reliable information and technology services in larger quantities has become a major task of both the academic community and the industrial world [4].

\section{The Current Teaching Situation and Main Problems}

At present, the problems of the teaching of communications engineering specialty primarily reveal in the fol- 
lowing three aspects.

\subsection{The Students Lack of Motivation for Learning}

The template is used to format your paper and style the text. All margins, column widths, line spaces, and text fonts are prescribed; please do not alter them. You may note peculiarities. For example, the head margin in this template measures proportionately more than is customary. This measurement and others are deliberate, using specifications that anticipate your paper as one part of the entire journals, and not as an independent document. Please do not revise any of the current designations. Considering the teaching work in recent years, as some students lack of motivation for learning, the students who have indifferent attitudes toward study are common, the absenteeism is more serious.

Most of the students have different interpretations for their learning purposes, some think that they go to college for the purpose of finding a good job in the future; some think that they have to do so because they have been admitted; only few students choose to study hard so as to achieve personal values.

In addition, as the college students have more free time, some become at a loss, and do not know how to arrange their spare time, and some even come to indulge in the online games and the Internet chats, unconsciously and gradually they begin to slack off psychologically, end in escaping the classes.

\subsection{Professional Courses Need to Be Updated}

The out-of-date teaching content is bad for the teaching, for the information technology has been rapidly developing; we urgently need to integrate the advanced technology into our teaching practice. However, despite the domestic and foreign communication professional teaching materials have changed a lot, it is a longer period from developing the new technologies to writing them into the teaching materials. Because the existing materials are difficult to reflect the current development of new concepts, applications and research, it is a challenging task to blend the current hot issues concerning the technological research and application in the communication disciplines in the teaching system.

\subsection{The Challenge of the Experimental Teaching Practice}

There exist such major problems in the current experimental teaching system as some experimental teaching models are so monotonous that they are lagging behind the rapid development of today's electronic and information technology.

The Communication Engineering teachers bear a certain amount of advanced scientific research projects, some of the research findings have been transformed into the experimental teaching content, which are only "tip of the iceberg." The students, especially the excellent undergraduates have no access to the latest technology, but rather remain in the knowledge in the books, which is very unfavorable to foster the innovative consciousness and abilities.

\section{Ideas and Practice Scheme}

In the light of the current situation and problems in the training of the Communication Engineering personnel, we summarize that the comprehensive strategy for the construction of the communication engineering specialty.

\subsection{The Course Construction}

As to the aspects of constructing the professional courses and improving the teaching quality, we focus on the construction of the specialized core course groups and professional orientation course groups. Through the construction of the specialized core course groups, we focus on the high-qualified teachers, improve the teaching quality of the specialized core course groups, enabling the students to lay solid foundations for mastering the knowledge of the follow-up professional courses.

In accordance with the current social needs for the professionals, there are the mobile communication orientation and the network communication ones set up in the specialty of communication engineering. Therefore, the construction of the professional orientation courses focuses on the construction of two core professional course groups, in the way of the teachers' scientific research teams stimulate the teaching teams, to achieve the good in- 
teraction between the teaching and the research, and introducing a large number of engineering projects, new technologies and new applications into the professional course teaching.

Meanwhile, in the process of the construction of the professional orientation course groups, we put emphasis on creating a few bilingual programs. The bilingual education has not only become an important indicator in the university teaching evaluation, but also an important task for the reform of university education. The most important purpose of language teaching is to improve the exchange of expertise, so as to carry out the international communication and cooperation, while allowing the students to learn the new knowledge and skills in their own majors.

\subsection{Construction of the College Students' Scientific and Technological Activities}

The college students' extra-curricular scientific and technological activities play an important role in the professional training and constitute an integral part of higher education teaching work, which are an important part of the campus culture and effective embodiment of style of study in the schools. The extra-curricular scientific and technological activities are practical ones in which the students identify, analyze and solve the problems by comprehensively using their knowledge and skills. Through the extra-curricular scientific and technological activities, the students can not only find out their own values, but also make it possible to do something in a lot of spare time, avoiding breeding of school weariness, which are conducive to the cultivation of the innovative consciousness and abilities.

We will gradually carry out the "continuous four years" activities, namely, the extra-curricular scientific and technological activities for the college students major in communication engineering, the specific practices are as follows:

- The credit system for the freshmen's extracurricular activities

In order to allow the freshmen to learn more about communication, electronic technology, and cultivate their interest in communications engineering, we take the lead in carrying out the elective credit system for the students who participate in the extra-curricular scientific and technological activities among our freshmen major in communication engineering. Each student can select the appropriate scientific and technological activities according to their interests and preferences.

- The elective courses concerning the electronic production for the sophomore

As the second year of university is a stage for the students to learn the specialized core courses, by creating the electronic production-related elective courses in combination with relative courses, the students can be effectively attracted to the electronic technology, so their interest can stimulate their enthusiasm for learning. By the students' designing the simple circuit and wire connections and commissioning by themselves, we can further improve their practical abilities, so as to lay good foundations for the students' future development as well as cultivate talents and reserve forces for the branch institute to participate in a variety of electronic design competitions.

- The research projects for junior students

By including the innovative education, which takes the innovative extra-curricular activities in science and technology as the main content, into the normative education system, we cultivate the students' innovative spirit and practical ability, inspire their innovative consciousness, improve their overall quality, create good style of study, and create a strong atmosphere of campus technology and academic research ,so as to guide them actively participate in the knowledge innovation and carry out scientific research as well as positively promote a large number of students into the students' research projects.

- Students in higher grades to participate in their teachers' research projects

The students in higher grades have completed specialized basic courses and some specialized courses, especially those have participated in various practical activities and student's research projects, they have already acquired the preliminary research capabilities. In order to further develop the students' abilities and sense of innovation, we guide and motivate the teachers to make their sub-topics of their research projects as the source of the students' topics of their graduate projects. By participating in their mentors' research projects, the students can learn how to behave themselves besides various practical skills. To experience the necessity of teamwork in the research team and understand the importance of responsibility, which are the greatest wealth that the scientific and technological activities brought to them. 


\subsection{Construction of Teacher Teams}

The teachers' research work is a source of teaching innovation, where there is no research there is no innovation. Practice shows that most of the well-known teaching masters in the domestic and foreign universities are scientists with strong research abilities and prominent scientific research achievements. The teachers good at scientific researches are not necessarily to do well in teaching, but the teachers who engage in no scientific researches are definitely bad at the university teaching work. Success in the scientific research is the basis for improving teaching quality.

Success in teaching is also an important way to promote the transformation of scientific research achievements and enhance the efficiency and quality of the scientific research.

By absorbing the students in higher grades into teachers' research projects and allow them to spread innovative thoughts, ideas, knowledge and methods college etc. through their practice, so as to turn them into productive forces or cultural consumer goods.

By organize the teachers with the same or similar specialties into a long-term cooperative team and carry out regular communication and exchanges among team members, we can achieve the information sharing teaching material and mutual exchanges of needed products in the aspects of case studies, research materials and teaching methods, so as to be favorable in updating the teaching content.

\section{Conclusion}

Based on highlighting the students' general education ,our talent training program puts emphasis on the cultivation of professional core basic knowledge, focusing on the orientation and flexibility of the specialties , attaching great importance to the teaching of the students' practical aspects, and further highlighting the students' practical skills training, and taking employment as the orientation in the aspects of training objectives, training requirements, curriculum and professional orientation setting as well as personnel training mode, so as to meet the demand for professionals in all kinds of enterprises and institutions.

\section{References}

[1] Ye, G.R., Chen, D.Q. and Wu, B.Y. (2009) On Research Oriented Teaching Model for College Undergraduate Students. China Higher Education Research, 3, 90-91.

[2] Wei, S.H. (2008) Research-Oriented Teaching Method and Training of Student's Creative Ability of Thinking. Journal of Shandong Teachers' University (Humanities and Social Sciences), 53, 68-72.

[3] Choi, J.H., et al. (2007) Project Driven Curriculum in the Mechanical Engineering Technology Program. Proceedings of the 2007 Middle Atlantic Section Fall Conference of the American Society for Engineering Education.

[4] Chen, H.-J. (2004) Refonn and Construction of Signals and Systems Course. Beijing: Journal of Eee, 6, 30-33. 